\title{
Perceptions on Floods by the Population Residing in the Watershed of Ribeirão Garcia, Brazil
}

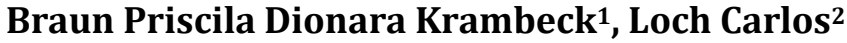 \\ ${ }^{1}$ Technology Center, Blumenau Regional University (FURB), Blumenau, Brazil \\ ${ }^{2}$ Technology Center, Santa Catarina Federal University (UFSC), Florianopolis, Brazil \\ Email: pbraun@furb.br, carlos.loch@ufsc.br
}

How to cite this paper: Krambeck, B.P.D. and Carlos, L. (2019) Perceptions on Floods by the Population Residing in the Watershed of Ribeirão Garcia, Brazil. Atmospheric and Climate Sciences, 9, 172-189. https://doi.org/10.4236/acs.2019.91012

Received: November 10, 2018

Accepted: January 21, 2019

Published: January 24, 2019

Copyright $\odot 2019$ by author(s) and Scientific Research Publishing Inc. This work is licensed under the Creative Commons Attribution International License (CC BY 4.0).

http://creativecommons.org/licenses/by/4.0/ (c) (i)

Open Access

\begin{abstract}
Any anthropic action transforms the environment. However, the Urbanization is a human achievement, not the "villain" or "protagonist" of passive actors and experienced environmental degradations, but the model of urban occupation, construction and densification, interconnected with the ineffectiveness of the current drainage system. When evaluating programs to minimize flood impacts, the social component is a necessary but often neglected dimension. This component can be evaluated through the articulation between the actors (population and public power) and the resident community's perception in relation to the needs and interventions. The present work seeks to analyze the perception of the community resident in the watershed of Ribeirão Garcia regarding the problems arising from urban floods. The repeated flood events occurring in the Ribeirao Garcia watershed in the city of Blumenau-SC, Brazil, make this place a potential area for an investigative process, which can subsidize future decision-making processes aimed at the adequacy of a sustainable system in medium and long term. For the accomplishment of this work, a qualitative research was adopted. Fieldwork and semi-structured interviews with residents in the sample areas have been carried out to analyse land use and occupation. The procedures that supported this sample survey were divided into four steps: definition of the total population and the sample size; preparation of a questionnaire; application of the questionnaire and tabulation of results. It can be seen that, despite the problems of floods and landslides to residents of all sample areas, the locals have different perceptions regarding the proposed issues and that these different perceptions are linked to the sample geographic location. The analysed space is full of contrasts in physical, social and economic aspects, which favours one part of the population and disfavours the other. The process of densification
\end{abstract}


and overcrowding of inadequate areas has been one of the negative effects of a disorganized housing sector in a speculative real estate market, and different levels of infrastructure among the districts, consolidating, in many ways, a process of social exclusion and spatial segregation. The analysis of the resident community's perception in the Ribeirao Garcia watershed shows that the most susceptible communities to this type of events are those of low income, located in risk areas. It also demonstrates that, despite these communities' present empirical situation knowledge on the causes and consequences of the floods, most residents prefer to transfer responsibility only to the public power, without assuming their own responsibility. The study of community perception makes it clear that the problem has been aggravated in part by a lack of knowledge of the relationship between land use and flooding.

\section{Keywords}

Flooding; Environmental Perception, Land Use, Occupation

\section{Introduction}

Floods are natural phenomena caused by the dynamics of nature and are intensified by anthropic intervention in the environment. The socio-environmental effects are aggravated as the land use and occupation process is inadequately carried out, in which the population, usually of low income, occupies places that are inadequate to living and are exposed to environmental and pathological risks.

The last fifty years have been marked by the accelerated growth of the Brazilian urban population, which grew from around 19 million in 1950 to over 190 million in 2010 [1]. However, during this period, state investments in urban infrastructure were insufficient. This gap has compromised environmental quality in urban settlements, directly affecting water resources.

The discussions and proposals regarding the urban infrastructure of Brazil have gradually evolved since the 1970s, especially when problems related to flooding in the urban area intensified. However, only in the 2000s the maturing of the discussions allowed the instrumentalization of tools that were proposed to mitigate the problems of "urban waters" from a modern perspective. In the evolution of this process the community's perception in relation to this topic emerges as a question to be investigated.

Although often disregarded, the perception of the social component is a necessary dimension in the evaluation of programs aimed at minimizing the impacts of floods. This component can be evaluated through the articulation between the actors (population and public power) and the resident community's perception in relation to risk, the needs and interventions [2] [3] [4].

During the last few decades, a crescent number of researchers have tried to respond to numerous questions, examining the opinions expressed by the people 
when questioned to assess the dangers to which they are, or which may be subject to future.

Every individual, when placed in front of a risk situation, tends to respond based on their beliefs, knowledge baggage and experience [5].

According to [6] the concept of risk is extremely complex, because, in addition to the scientific factors, it is intrinsically associated with social elements and their perception. The risks involve many difficult-to-measure uncertainly.

The investigation team of the Decision research Center, Oregon, directed by Paul Slovic and Baruch Fischhoff, was one of the pioneers in this field of research. Through the work developed by this team, it has shown that the risk assessment by the laity does not resemble those of the experts, because people in their day-to-day do not make estimates of probabilities, therefore their thinking never it can be summed up from a one-way perspective [7].

This current research also had the merit of contributing to the affirmation of this current with decision makers, influencing decisively the new strategies for disseminating information and disseminating technical knowledge among the populations.

In the current national context of environmental management, and specifically of water resources, participatory and decentralized processes are prioritized and must incorporate the civil society. Therefore, the opinion and perception of the population affected by the problems and interventions can be an important tool in conducting processes of urban transformation and (re)formulation of public policies.

Based on this assumption, the present work seeks to analyze the perception of the community resident in the watershed of Ribeirão Garcia as to the problems arising from urban floods.

The repeated flood events occurring in the Ribeirão Garcia watershed, Blumenau-Brazil make this area a potential space for an investigative process, which can support future decision-making processes aimed at the adaptation of a sustainable system in the medium and long term.

\section{Characterization of Study Area}

The Ribeirão Garcia Watershed is located in the south of Blumenau City (SC), in the low valley of the Itajaí-Açu River with a territorial dimension equivalent to $158.9 \mathrm{~km}^{2}$, representing approximately $30 \%$ of the total surface of the municipality. It is located between the co-ordinates: $26^{\circ} 55^{\prime}$ and $27^{\circ} 08^{\prime}$ of South Latitude and $49^{\circ} 01^{\prime}$ and $49^{\circ} 10^{\prime}$ of Greenwich West Longitude, spindle 22 (Figure 1).

The drainage system of Ribeirão Garcia is developed on the right bank of the Itajaí-Açu River, with the confluence of the water courses occurring within the urban site of the municipality of Blumenau. The Garcia Stream is approximately $41.7 \mathrm{~km}$ long from the main source to the mouth of the Itajaí-Açu River. It crosses the city from the south to the north, comprehending almost totally the southern region. The headwaters of its main forming streams are located about 


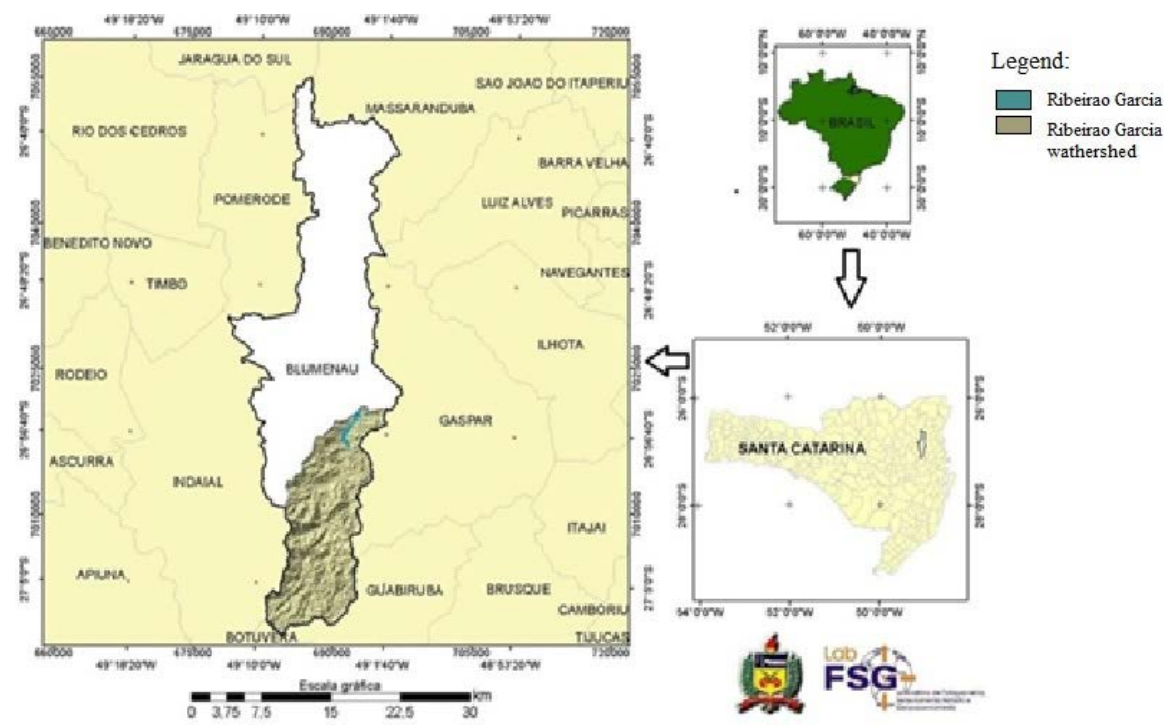

Figure 1. Location map of the Ribeirão Garcia watershed in the municipality of Blumenau.

$24 \mathrm{~km}$ straight south from the centre of Blumenau, in a mountainous region within the area of environmental preservation, called "Parque das Nascentes" with 5300 ha of extension in the highest parts of the watershed (Figure 2).

The urban space of Blumenau presents notable differences in topography and relief morphology, with altimetric amplitudes and systems of steeper slopes to the south of the city. The Garcia Valley, especially the low course, constitutes a landscape strongly conditioned by processes of anthropogenic derivation and is considered the most critical area of the municipality. The anthropic action has aggravated the flood events and intensified the processes of landslides.

Geologically, the river watershed of Ribeirão Garcia is positioned on three distinct stratigraphic units (Figure 3(a)): to the south, Itajaí Group, composed of sandstones of the Gaspar Formation; secondly, the argillite and layered siltstones of the Campo Alegre Formation; in the south-extreme, the Brusque Metamorphic Complex, composed of rocks with low metamorphic degree, represented by shale and basements of the Itajaí-Flank South Group [8] [9]. From a hydrological point of view, the Itajaí group is an important aquifer because it has high porosity and permeability. Geomorphologically, the Ribeirão Garcia Watershed is installed on the Santa Catarina shield (Figure 3(b)), where transcurrent geological faults create the $\mathrm{V}$-shaped valleys, characterized by steep slopes and deep valleys, where the main rivers flow.

The Ribeirão Garcia watershed presents a marked upward slope, where the altimetric bands are superior to $900 \mathrm{~m}$ and are located in the Itajaí mountain range. Altitudes lower than $50 \mathrm{~m}$ are more representative in the vicinity of the Ribeirão Garcia exudate (Figure 4).

From the pedological point of view (Figure 5(a)), the non-hydromorphic Alic Cambisols (aluminum saturation $\geq 50 \%$ ) predominate in the watershed, characterized by an incipient $\mathrm{B}$ horizon, low textural gradient and the medium to high 


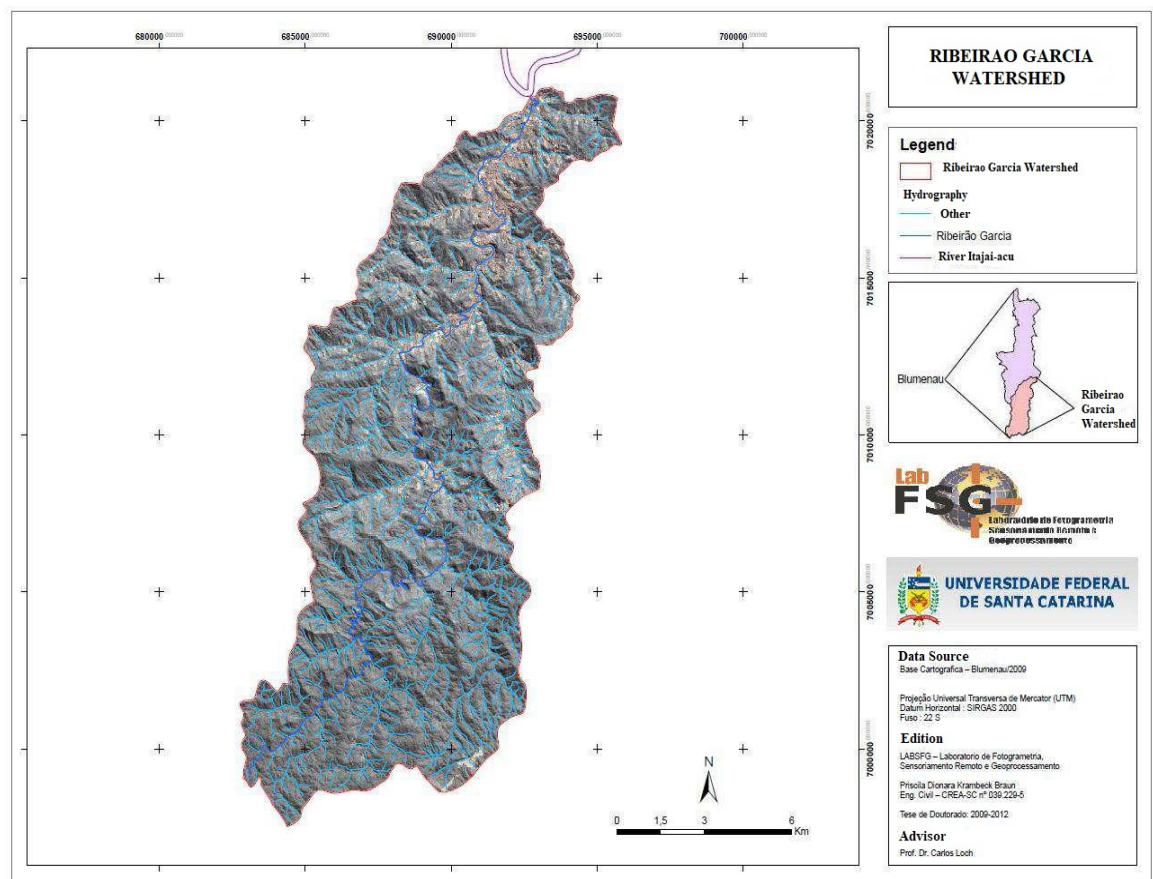

Figure 2. Drainage network of the Ribeirão Garcia Watershed.

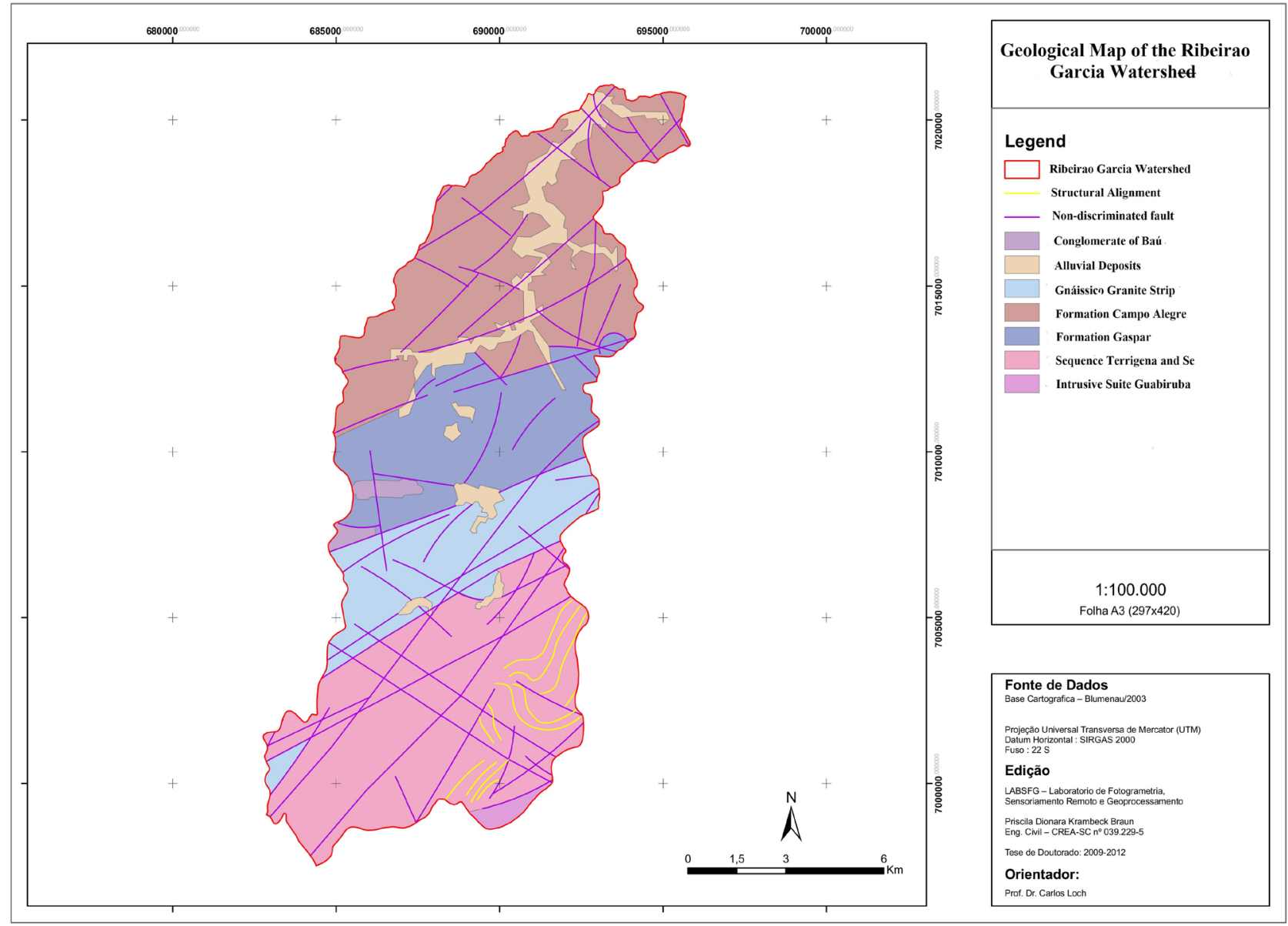

(a) 


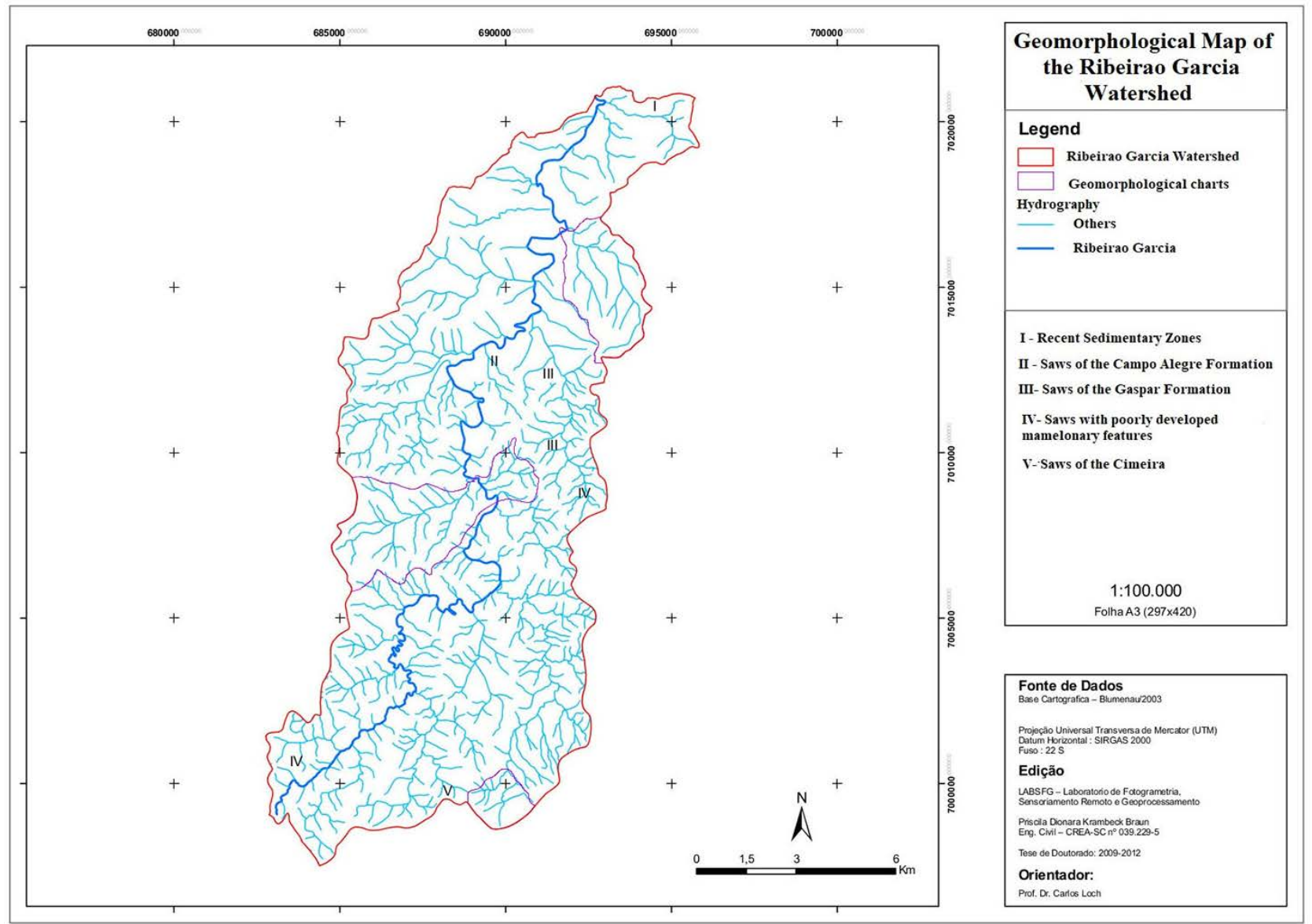

(b)

Figure 3. (a) Geological map of the Ribeirão Garcia Watershed and (b) Geomorphological map of the Ribeirão Garcia Watershed.

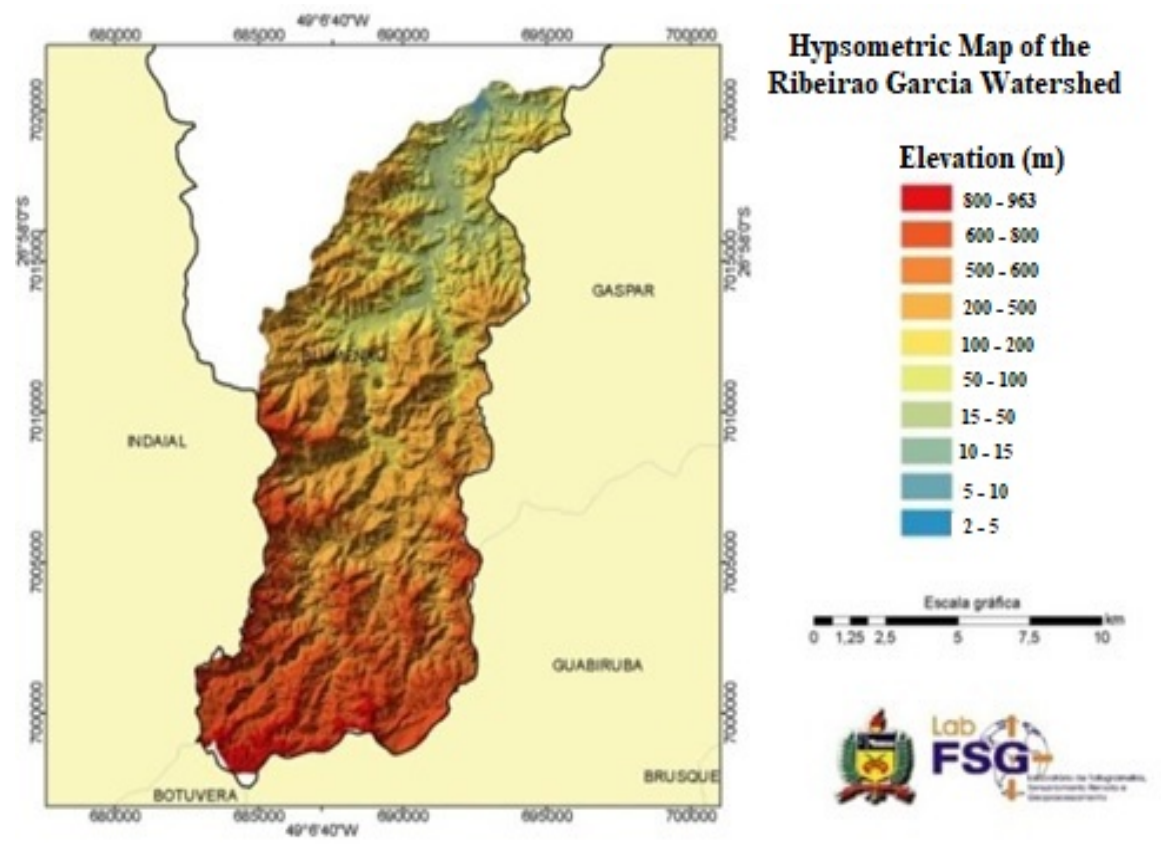

Figure 4. Hypsometric map of the Ribeirão Garcia Watershed. 


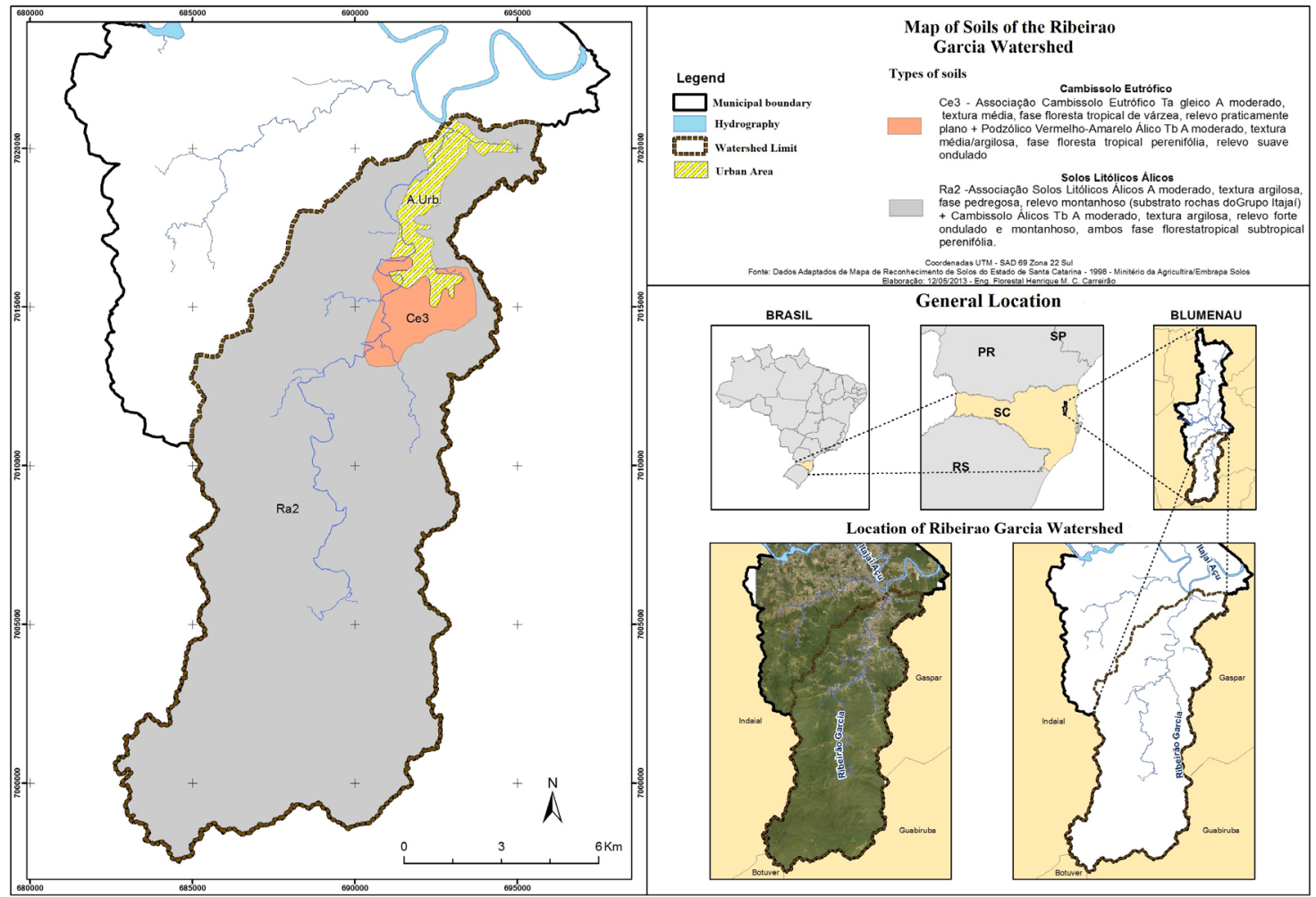

(a)
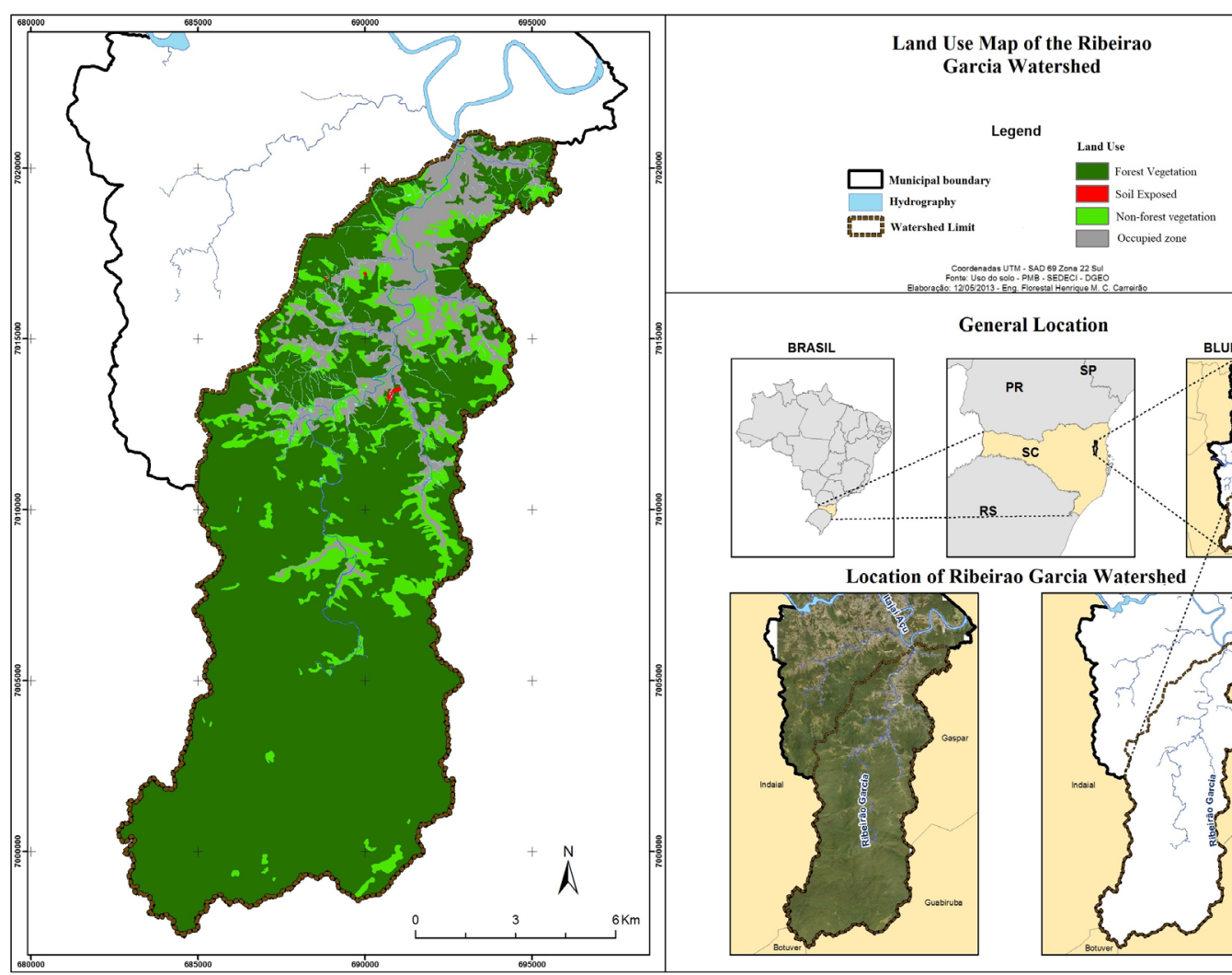

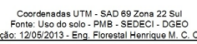

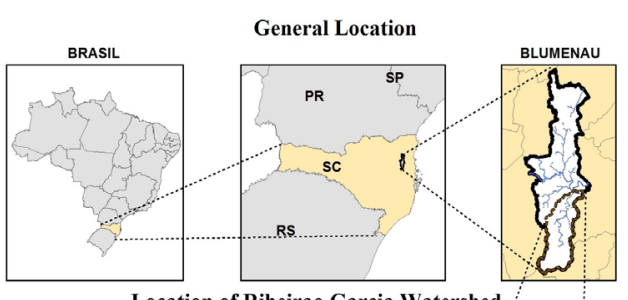

Location of Ribeirao Garcia Watershed
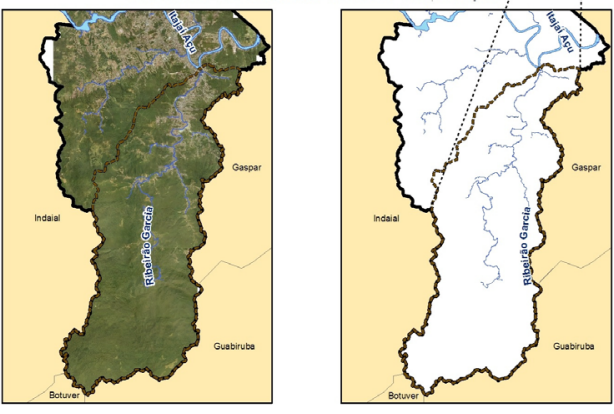

(b)

Figure 5. (a) Soil map of Ribeirão Garcia Watershed and (b) Forest cover map. 
silt/clay. Soils usually have sequences of horizons A, B and C, with variations in depth, colour, texture and structure [10]. Considering the Plant Cover, the Ribeirão Garcia Watershed presents a good natural vegetation cover (Atlantic Forest) in the most mountainous parts, concentrated in areas of the Faxinal Farm, Spitzkopf Hill, Artex and extensive areas of pine and eucalyptus reforestation, as well as recent reforestation of several palm tree species (Figure 5(b)).

The high altimetric range of Blumenau municipality and the proximity to the Atlantic coast $(40 \mathrm{~km})$ create climatic conditions typical of the city and, consequently, of the Ribeirão Garcia watershed.

According to Wladimir Köppen's classification, the region of Blumenau fits the Cfa climate type. In climates of group $\mathrm{C}$ (climate group indicator), the temperature of the coldest month varies between $18^{\circ} \mathrm{C}$ and $-3^{\circ} \mathrm{C}$, whereas the temperature of the warmer months remains above $10^{\circ} \mathrm{C}$.

The Cf type of climate (according to the rainfall regime) presents rains equally distributed throughout the year, with no dry season.

The urban area of the watershed occupies approximately $14.06 \mathrm{~km}^{2}$. Most of the population is concentrated in the central portion of Ribeirão toward the mouth, and they inhabit the following neighbourhoods: Garcia, Progresso, Gloria, Valparaiso, Ribeirão Fresco, Vila Formosa, Centro and Jardim Blumenau (Figure 6).

The Ribeirão Garcia Watershed is the most populous area of the municipality, with 47,577 thousand inhabitants (Table 1), and a large part of this population suffers with the floods. Blumenau City Hall considers that the Garcia district has reached the limit of occupation (spatial limit) registering a true demographic explosion towards the tops of the chains of hills of Itapuí Street, that delimits it [11].

As for the economic aspects, according to Blumenau [11], the primary sector of agriculture is developed in small mini-farms, with holistic culture and still significant crops of banana, corn, cassava, rice, sweet potatoes and others. With respect to the industrial sector, Blumenau has approximately 1750.00 industries, being textiles, clothing, metallurgy and civil construction the most significant branches. Under the aspect of mineral resources, specifically, the clay slates of the Itajaí group may be significant in the floor paving area.

The main human activities found in the rural portion of the watershed are concentrated in subsistence agriculture, livestock, fish farming and leisure.

\section{Methods and Materials}

For the accomplishment of this work, a quantitative research was adopted. Fieldwork and semi-structured interviews with the residents of the sample areas were carried out to analyze land use and occupation.

The procedures that supported this sample survey were divided into four stages: definition of the total population and sample size; preparation of a questionnaire; application of the questionnaire and tabulation of results. 


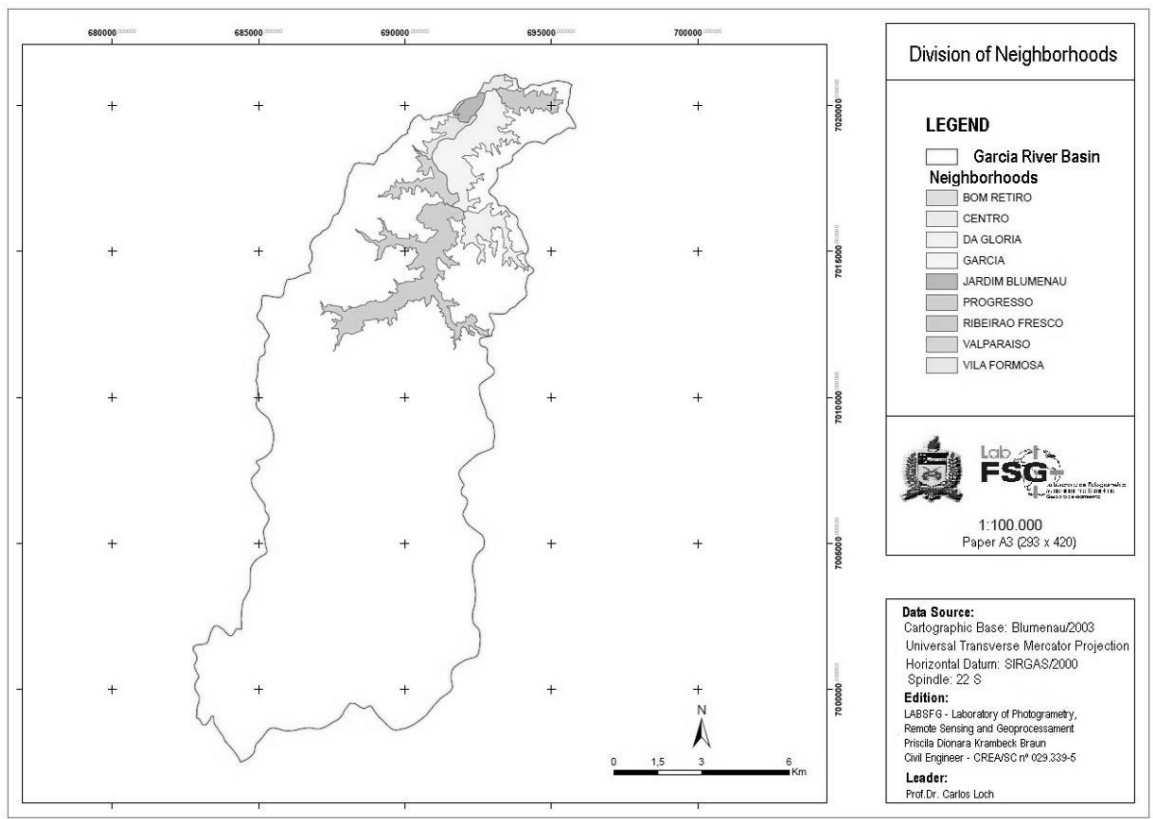

Figure 6. Neighbourhoods of the Municipality of Blumenau/SC located in the watershed of Ribeirão Garcia.

Table 1. Area in $\mathrm{km}^{2}$ and projection of population (total), number of households and density (inhabitants per $\mathrm{km}^{2}$ ), by the new neighbourhood division-Blumenau 2010-located in the Ribeirão Garcia Watershed.

\begin{tabular}{|c|c|c|c|c|}
\hline \multirow{2}{*}{ Neighbourhoods } & \multirow{2}{*}{ Area in $\mathrm{km}^{2}$} & Total & \multirow{2}{*}{$\mathrm{N}^{\bullet}$ of households } & \multirow{2}{*}{$\begin{array}{c}\text { Density } \\
\left(\text { inhab./ } / \mathrm{km}^{2}\right)\end{array}$} \\
\hline & & Population 2010 & & \\
\hline Da Glória & 1.95 & 6228 & 5,526 & 3069 \\
\hline Garcia & 4.53 & 15,911 & 5336 & 3498 \\
\hline Jardim Blumenau & 0.64 & 2855 & 1004 & 2988 \\
\hline Progresso & 6.68 & 15,005 & 4852 & 2003 \\
\hline Ribeirão Fresco & 1.22 & 1587 & 513 & 1045 \\
\hline Valparaíso & 1.42 & 5280 & 1912 & 3767 \\
\hline Vila Formosa & 0.8 & 711 & 242 & 818 \\
\hline TOTAL & 17.24 & 47,577 & 19,385 & 2759.69 \\
\hline
\end{tabular}

The definition of the local population was based on the population projection per districts for the Municipality of Blumenau, conducted by the Brazilian Institute of Geography (IBGE) for the year 2010 presented in Table 1.

For this work the sample system was chosen by representative units, since it presents greater ease of sample selection and greater precision when compared to the random sample system.

It should be emphasized, however, that the use of the technique of sample surveys to survey social perception and changes in behaviour in relation to urban drainage, especially after prevention and restoration programs, should be 
considered. The time to detect such transformations is uncertain, and in this case, a continuous process of sampling research that allows a temporal monitoring in the study area should be applied [12].

According to Cochan [12] and Bolfarine and Bussabi [13], the pattern of the samples is systematic, that is, chosen according to a classification. Representative samples were selected from a pre-categorization of the urban Basin area into three landscape units: high, medium and low Garcia, because the geographical position of the sample changes the perception of the resident community (geographical perception). Factors such as relief, land use and occupation, macro-zoning and zoning, and value plan.

Six homogeneous zones/samples were selected (Figure 7), two located at the top (samples 5 and 6), two in the middle (samples 3 and 4) and two on the low Garcia (samples 1 and 2), with an area of approximately $234,406.00 \mathrm{~m}^{2} /$ each, so that each sample corresponds to approximately $1.5 \%$ of the total urbanized area of the watershed, totalling $10 \%$ of the total urbanized area, base year 2009 .

Six sampling zones were chosen because natural disasters, among them, the flooding affect people in different forms in function of their geographical location in the watershed.

The floor high amplitude found between the high and the middle Garcia condition the shallow-breast-feeding, causing the water to reach the lower areas with great speed, thus generating greater damage. This dynamics generates intensities of damage and different perceptions.

The samples were physically characterized for their location, geology, geomorphology, pedology, drainage network, and were characterized for their attributes established in the Municipal Master Plan, such as: Macrozoning, Zoning and Value Plan (Table 2).

In the study areas, city schools of elementary level were selected, named sample bases (Table 3), located in each selected sample area, totalling approximately

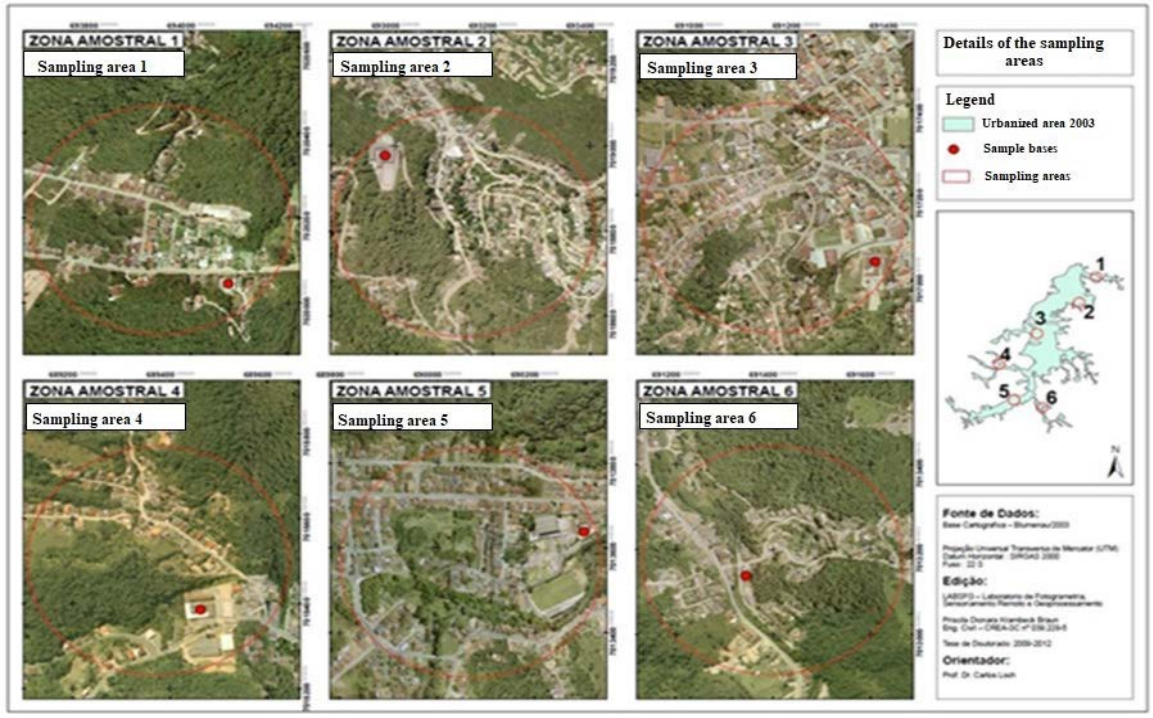

Figure 7. Detailing of sample areas. 
Table 2. Characterization of sample zones.

\begin{tabular}{|c|c|c|c|c|c|c|c|c|}
\hline Zones & Location & $\begin{array}{c}\text { Geological } \\
\text { Characteristics }\end{array}$ & $\begin{array}{l}\text { Geomorphological } \\
\text { Characteristics }\end{array}$ & $\begin{array}{c}\text { Pedological } \\
\text { Characteristics }\end{array}$ & $\begin{array}{l}\text { Characteristics of the } \\
\text { drainage network }\end{array}$ & Macrozoning ${ }^{1}$ & Zoning $^{2}$ & Value Plan $^{3}$ \\
\hline 1 & $\begin{array}{l}\text { Lower Garcia/Ribeirão } \\
\text { Fresco neighbourhood. }\end{array}$ & Itajaí Group and & & Prevalence of & & & ZR 1 and 2 & \\
\hline 2 & $\begin{array}{l}\text { Lower Garcia/Garcia } \\
\text { Neighbourhood: region } \\
\text { of Araranguá street and } \\
\text { its cross streets. }\end{array}$ & $\begin{array}{l}\text { alluviums of the } \\
\text { Itajaí-açu river and } \\
\text { its tributaries }\end{array}$ & Closed "V" Valleys & $\begin{array}{l}\text { Neosols and, to } \\
\text { a lesser extent, } \\
\text { of Cambisols } \\
\text { and Argisols }\end{array}$ & $\begin{array}{c}\text { multidirectional } \\
\text { network obeying the } \\
\text { dendritic rectangular } \\
\text { pattern. }\end{array}$ & $\begin{array}{c}\text { Consolidation } \\
\text { area }\end{array}$ & ZR-1 & $\mathrm{ZF} 2$ \\
\hline 3 & $\begin{array}{l}\text { Medium Garcia/Garcia } \\
\text { Neighbourhood: region } \\
\text { of Zendron street and its } \\
\text { cross streets. }\end{array}$ & $\begin{array}{l}\text { Itajaí Grou / } \\
\text { Campo Alegre } \\
\text { Formation. }\end{array}$ & Closed "V" Valleys & Thick, & Ordered & & & \\
\hline 4 & $\begin{array}{c}\text { Medium Garcia/ } \\
\text { Progresso } \\
\text { Neighbourhood: Rui } \\
\text { Barbosa, Gustavo Maier } \\
\text { and Leopoldo Heringer } \\
\text { streets and their cross } \\
\text { streets. }\end{array}$ & $\begin{array}{l}\text { Itajaí Group } \\
\text { (Campo Alegre } \\
\text { Formation) and } \\
\text { alluviums of the } \\
\text { Krohberger stream } \\
\text { and its tributaries. }\end{array}$ & $\begin{array}{l}\text { Valley closing in } \\
\text { "V", steep slopes and } \\
\text { elongated } \\
\text { ridge-shaped hills. }\end{array}$ & $\begin{array}{l}\text { predominantly } \\
\text { clayey and } \\
\text { poorly friable } \\
\text { soils. }\end{array}$ & $\begin{array}{c}\text { multidirectional } \\
\text { network obeying the } \\
\text { dendritic rectangular } \\
\text { pattern. }\end{array}$ & $\begin{array}{c}\text { Development } \\
\text { consolidation area }\end{array}$ & $\begin{array}{l}\text { ZR-1, ZR-2 } \\
\text { and ZLE1 }\end{array}$ & ZF 2 \\
\hline 5 & $\begin{array}{l}\text { Higher Garcia/Progresso } \\
\text { Neighbourhood: } \\
\text { Helmuth Goll street and } \\
\text { its cross streets. }\end{array}$ & $\begin{array}{l}\text { Itajaí Group } \\
\text { (Campo Alegre } \\
\text { Formation) and } \\
\text { alluviums of the } \\
\text { Itajaí-açu river and } \\
\text { its tributaries }\end{array}$ & Closed "V" Valleys & $\begin{array}{l}\text { Thick, } \\
\text { predominantly } \\
\text { clayey and } \\
\text { poorly friable } \\
\text { soils. }\end{array}$ & $\begin{array}{c}\text { Ordered } \\
\text { multidirectional } \\
\text { network obeying the } \\
\text { dendritic rectangular } \\
\text { pattern. }\end{array}$ & $\begin{array}{c}\text { Development } \\
\text { consolidation area }\end{array}$ & ZR-2 & $\mathrm{ZF} 2$ \\
\hline 6 & $\begin{array}{l}\text { Higher Garcia/Jordao } \\
\text { Neighbourhood. }\end{array}$ & $\begin{array}{c}\text { Itajaí Group on } \\
\text { Gaspar Formation. }\end{array}$ & $\begin{array}{c}\text { Gaspar Formation } \\
\text { Hills }\end{array}$ & & & $\begin{array}{c}\text { Controlled } \\
\text { densification area }\end{array}$ & $\begin{array}{l}\text { ZR } 1, \text { ZR } 2 \\
\text { and ZLE } 1\end{array}$ & \\
\hline
\end{tabular}

${ }^{1}$ Macrozoning: Consolidation Area-it covers already urbanized areas, whose occupation will be achieved by intensifying the land use in a balanced way in relation to services, infrastructure, equipment and environment, in order to avoid their idleness or overloading and optimize collective investments. Controlled densification area-already urbanized areas or not, which need to be controlled by the geological, topographical, hydrological and urban factors. ${ }^{2}$ Zoning: Residential Zone $1-Z R 1-A$ territorial area characterized by low density with height limitation. Residential Zone 2-ZR2-It is a territorial area with low density, without limitation of height. Special location Zone-ZLE 1-A territorial space considered of importance for the development of the city, intended for cultural protection and/or the development of tourist attractions and relevant landmarks. Obs. The Urbanization Coefficients of Residential Areas 1 and 2 and of the ZLE 1 Special Zone, as well as the proportion of each zone, covered by the zoning in each sample area, are presented in Annex 3. ${ }^{3} \mathrm{ZF}$-Fiscal Zone.

Table 3. Sample bases and their addresses.

\begin{tabular}{ccc}
\hline SAMPLE & SAMPLE BASIS & ADDRESS \\
\hline 1 & EBM Pastor Faulhaber & Rua Pastor Oswaldo Hesse, $\mathrm{n}^{\circ}$ 1.090-Ribeirão \\
2 & EBM Prof ${ }^{\mathrm{a}}$. Alice Thiele & Fresco \\
3 & EBM Prof Júlia Strzalkowska & Rua Carl Heinz Buechler, $\mathrm{n}^{\circ}$ 171-Garcia \\
4 & EBM Henrique Alfarth & Rua Rui Barbosa, $\mathrm{n}^{\circ}$ 1.616-Progresso \\
5 & EBM Pedro II & Rua Helmuth Goll, $\mathrm{n}^{\circ}$ 579-Progresso \\
6 & EBM Capitão Euclides de Castro & Rua Jordão, $\mathrm{n}^{\circ}$ 2.269-Progresso \\
\hline
\end{tabular}

3450 students, inserted in the sample areas of the watershed of the Garcia stream.

The community assessment was performed through a questionnaire. At each sample basis, a questionnaire was given to the students, to be completed by their parents. The questionnaire was designed to identify two main aspects: the resident community's environmental perception in relation to urban drainage; and the community's perception of state action (Figure 8). 


\section{RESEARCH QUESTIONNAIRE}

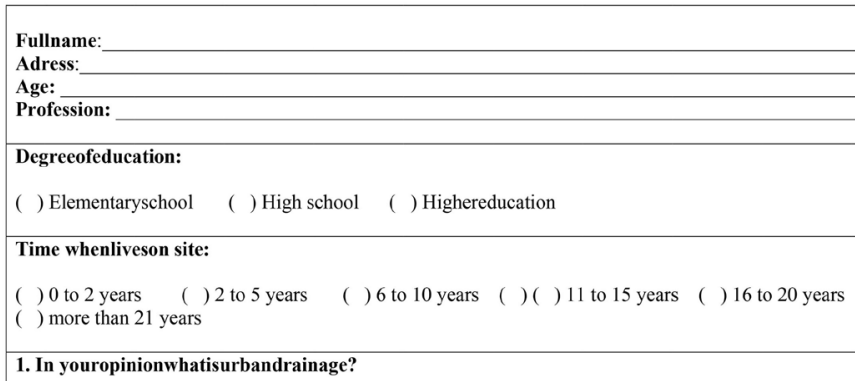

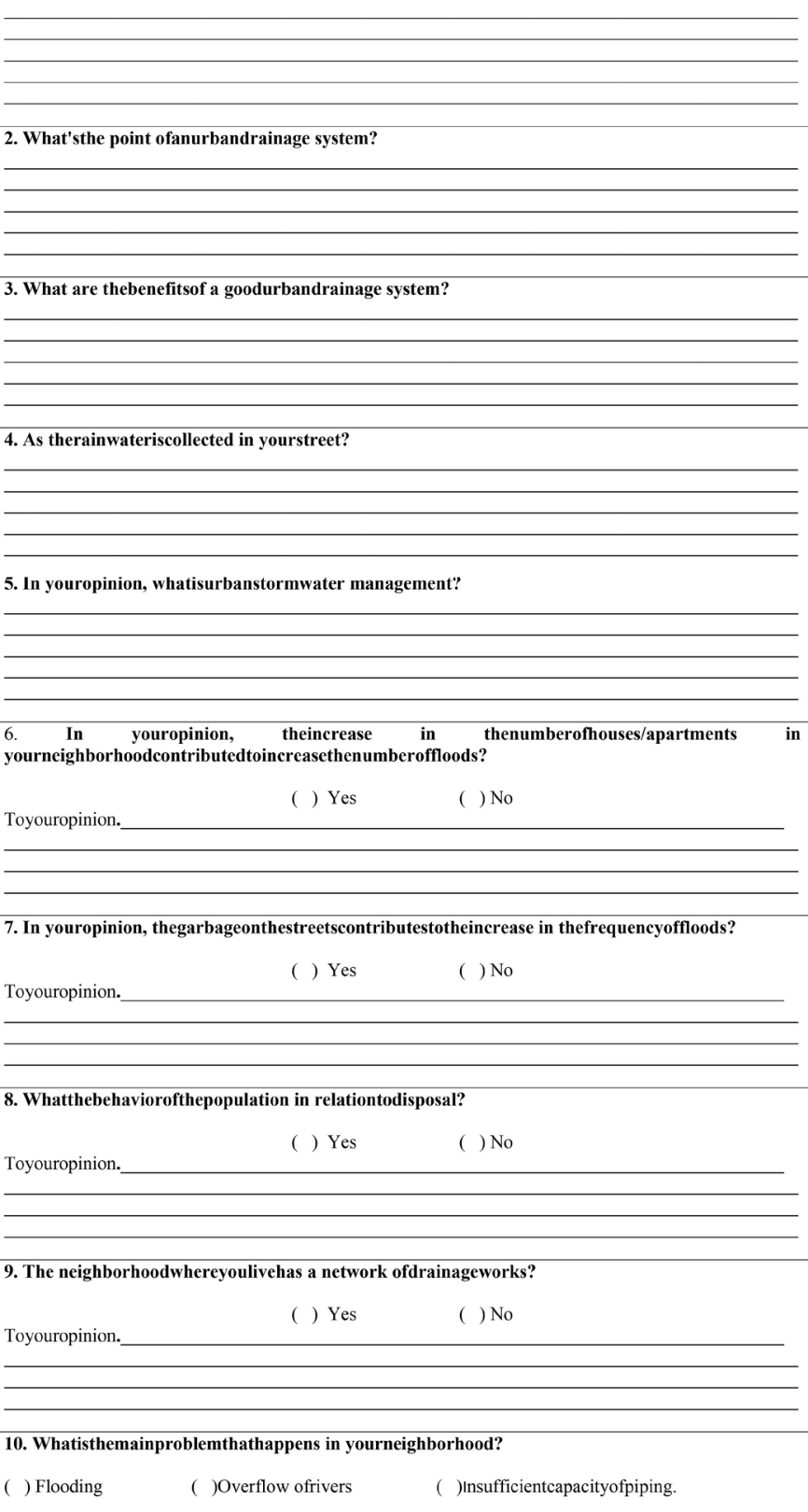

Figure 8. Model of the proposed questionnaire. 


\section{Results and Discussion}

Of the 3450 questionnaires applied, 2193 returned, corresponding to $63.57 \%$ of the total number of applied questionnaires. The results were analysed through descriptive statistics.

Regarding the age structure of the sample, the majority of interviewees are between 30 and 50 years old. Overall, few young people between 20 and 30 years old or adults over 50 were interviewed (Table 4). Most of the interviewees have been in the study area for at least 10 years, which gives them credibility when analysing the proposed questions.

In relation to the level of education, the majority of the interviewees attends or only attended elementary school. As the age group compatible with this level of education (6 - 14 years) was not contemplated by this research, one can conclude about the residents of the region have low level of education (Table 4).

The results are related to the main directions of the questionnaire: the resident community's environmental perception in relation to the urban drainage and the community's perception in relation to the state action (Figure 9).

The interviewees, residents in the districts inserted in the Ribeirão Garcia watershed, which in many cases suffer with the flooding problem, showed a great deal of discontent with the situation which they are subjected to. Many of them verbally reported that they had filed lawsuits against Blumenau City Government, requesting measures that would alleviate the problems. The added that the measures taken by the public power were insufficient or inefficient and that the problem persists.

It can be noticed that, despite the problems of floods and landslides to residents of all sampled areas, the inhabitants have different perceptions regarding the proposed issues and that these different perceptions are linked to the sample geographic location (Figure 10).

The interviewees residing in samples 5 and 6 , located more upstream of the Ribeirão Garcia watershed and whose residences present a constructive pattern considered of medium and high standard, recognize their own contribution to the flood process, but blame the public power for neglecting the maintenance of urban micro and macro drainage systems and question the occupation model adopted by the public power for the areas in which they are inserted.

Table 4. Interviewees' age levels and levels of education.

\begin{tabular}{|c|c|c|c|c|c|}
\hline Schooling Age Group & $20-30$ & $31-40$ & $41-50$ & $>50$ & Total \\
\hline No & 0 & 8 & 27 & 31 & 66 \\
\hline Elementary School & 65 & 1085 & 190 & 86 & 1426 \\
\hline High School & 83 & 154 & 134 & 13 & 384 \\
\hline Higher Education & 175 & 95 & 47 & 0 & 317 \\
\hline Total & 323 & 1342 & 398 & 130 & 2193 \\
\hline
\end{tabular}




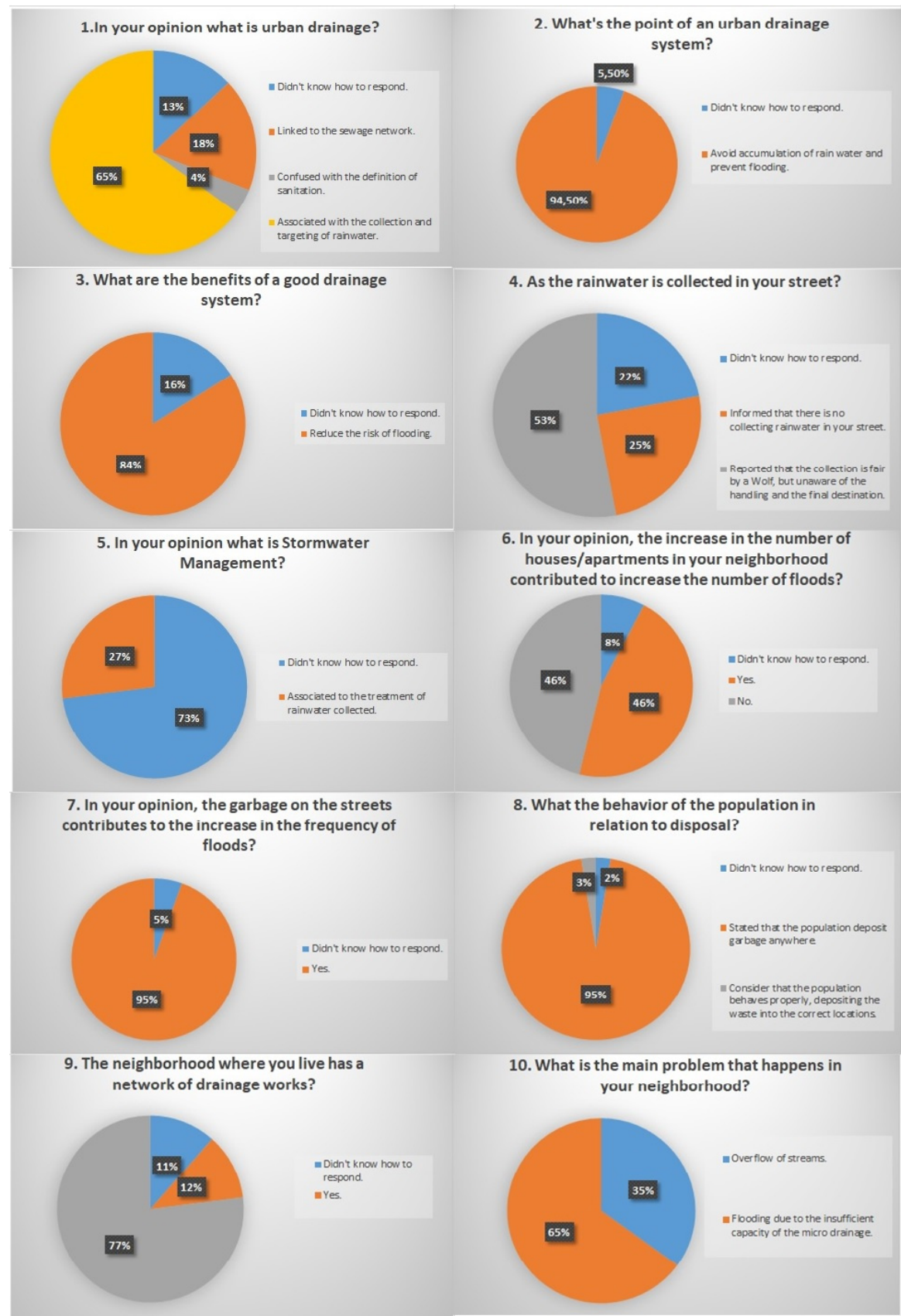

Figure 9. Questionnaire results.

However, the reality presented by this first group is totally different from that of the residents of samples 1, 2, 3 and 4, where the interviewees' houses were built on the banks of streams, in waterways (thalwegs) and areas subject to landslides, in many cases without any planning, security or infrastructure. Large parts of the residents in the streets inserted in these samples are in irregular subdivisions and have shown a great desire to be relocated by the city government to other areas of the city. It is noticed that, to a large extent, these residents blame the public power for the problems to which they are subjected to and do not recognize their own contribution to this process. 


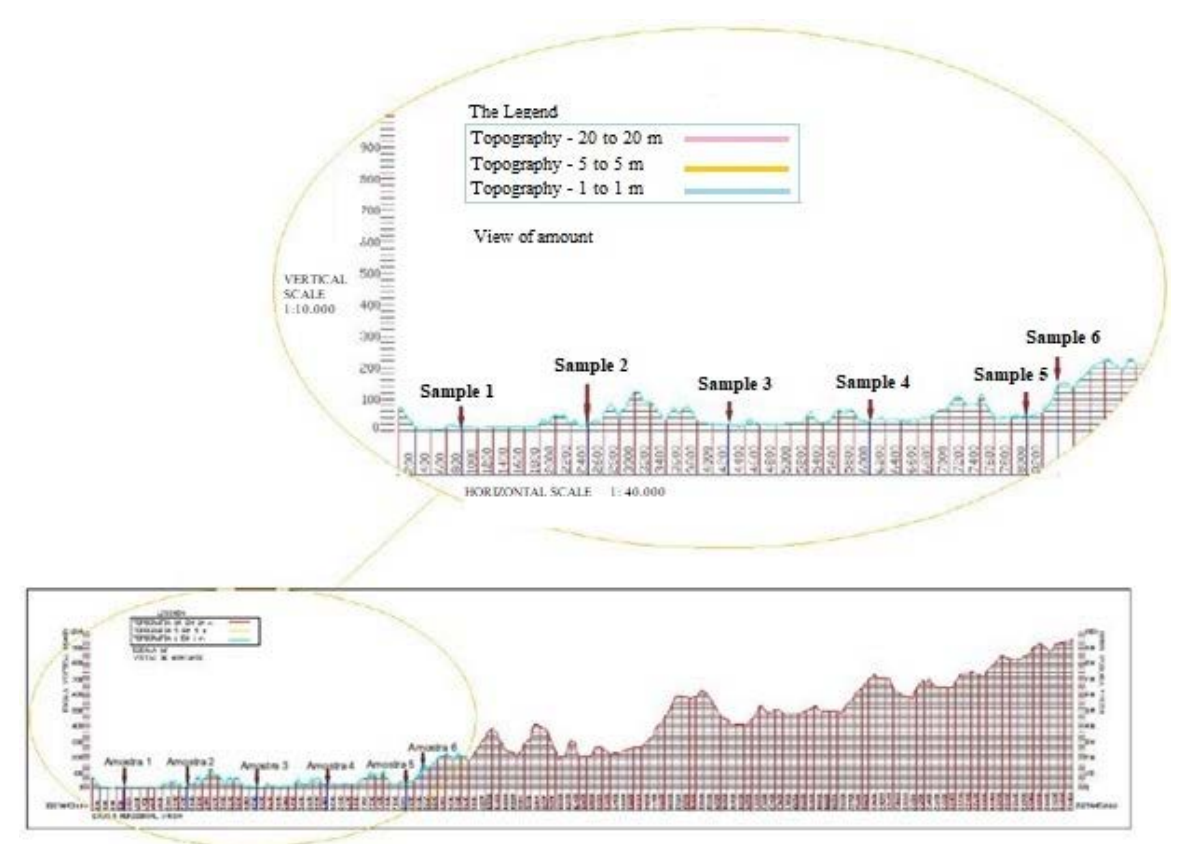

Figure 10. Longitudinal profile of the Ribeirao Garcia watershed with spatialization of the sample areas.

The analyzed space is full of contrasts, in physical, social and economic aspects, which favours one part of the population and disfavours another, since the process of densification and over-occupation of inadequate areas has been one of the negative effects of a disorganized housing sector, a speculative real estate market and different levels of infrastructure among neighbourhoods, consolidating, in many aspects, a process of social exclusion and spatial segregation.

The presence of subnormal occupations occurs mainly in the areas farthest from the watershed, making it even more difficult to implement infrastructure and sanitation for these families. However, there are small outbreaks of subnormal occupations in the middle of areas near the central region of the municipality, in lands with high added value that resist to real estate speculation.

It can be verified that the lack of efficient and effective urban planning has caused disastrous environmental effects, besides the worsening of social disparities and loss of population's living quality. Urban sustainability is a priority and must be built day-to-day, and part of that construction is based on the legitimacy of public policies that must be constantly updated. These policies must adapt to the demands of urban services as well as to social and environmental demands.

Understanding the problem of floods as a process depends mainly on understanding the (non-linear) history of their production, the model of urban development, and the perception that the resident population has of the problem.

The present urban network of the city of Blumenau and, consequently, of the Ribeirão Garcia watershed, is strongly conditioned by the colonial land structure. It still perpetuates allotments with a single street, non-existence of secondary streets and perpendicular to the level curves. 
Although the urban legislation seeks to improve the conditions for the implantation of allotments, the inheritance of the colonial period, that is, the land structure, associated to the relief of the city, prevents effective improvements.

One must not forget that the occupation of space, essentially when it does not comply with the spatial planning, can aggravate situations of risk. In the case of Blumenau, the form of occupation of the territory undoubtedly increased the exposure to the risk of floods and landslides.

It is worth noting that infrastructure is decisive in mitigating or amplifying the consequences of a natural disaster. Infrastructure networks, such as roads and bridges, that allow people, goods, services and information to circulate, as well as the means of distress and emergency, can determine, in areas of equal susceptibility, different degrees of vulnerability on the part of the population.

However, public power alone does not represent a panacea for the solution of these socio-environmental problems. Together with efficient public policies, another sphere must act for an effective change of the situation, and this sphere is represented by education. People's attitude toward nature may change over time.

The resident population in the Ribeirão Garcia watershed is one of the facets of the flood problem in that area, since it contributes to increase the frequency and intensity of flooding, due to a lack of knowledge and a public housing policy aimed at the low income population.

The studies of environmental perception are important tools and support the formulation of guidelines aimed at the implementation of an Environmental Education work, in which a change in the scale of attitudes and rescue of values can be promoted, leading to behavioural changes and social transformations.

Environmental Education plays an important role in the reflection of environmental problems through social awareness, which implies a process of reflection and understanding of the environmental processes, leading to people's participation and the recovery of citizenship in decision making processes. It also allows people to develop a more comprehensive vision, through which attitudes and skills are developed, aiming at the citizens' critical and participatory action in the environment they are inserted in and interact with.

\section{Conclusions}

The method adopted allowed to cover a representative portion of the community and that the collected data were sorted and structured, allowing them to be transformed into useful and credible information.

Information that can help the public to direct their actions based on more comprehensive and consistent information, as well as to plan and develop their fact-based projects, reflected in data.

The analysis of the resident community's perception of the Ribeirão Garcia watershed shows that the most susceptible communities to this type of event are those of low income, located in risk areas. It also demonstrates that, although 
these communities present an empirical knowledge about the causes and the consequences of the floods, most of them prefer to transfer responsibility only to the public power, without assuming their share of it.

The study of the community's perception makes it clear that the problem has been aggravated, in part, by the population's lack of knowledge about the relationship between land use and floods. The community needs to be transformed into a partner of the public power and this will only be possible through environmental education.

The incorporation of information about the occupation of the study area, about the involved population's needs and aspirations, seeking understanding about the causes and consequences of floods, is aimed at guiding the decision-making process.

\section{Conflicts of Interest}

The authors declare no conflicts of interest regarding the publication of this paper.

\section{References}

[1] IBGE (Instituto Brasileiro de Geografia e Estatística) (2010) Censo Demográfico 2010: agregado por Setores Censitários dos resultados do universo. IBGE, Rio de Janeiro, RJ.

[2] Casagrande, D.G. (1997) Values, Perceptions and Restorations Goals. In: Casagrande, D.G., Ed., Restoration of an Urban Salt Marsh an Interdisciplinary Approach, Yale School of Forestry and Environmental Studies, New Haven, Connecticut, $62-75$.

[3] Purcell, A.H. (2004) A Long-Term Post Project Evaluation of an Urban Stream Restoration Project Baxter Creek, El Cerrito, California. Water Resources Center Archives, University of California, Berkeley, 15 p. http://repositories.edlib.org/wrca/restoration/purcell

[4] Larned, S.T., Suren, A.M., Flanagan, M., Biggs, B.J.F. and Riis, T. (2006) Macrophytes in Urban Stream Rehabilitation: Establishment Effects, and Public Perception. Restoration Ecology, 14, 429-440. https://doi.org/10.1111/j.1526-100X.2006.00151.x

[5] Peres, F., Rozemberg, B. and de Lucca, S.R. (2005) Percepção de riscos no trabalho rural em uma região agrícola do Estado do Rio de Janeiro, Brasil: agrotóxicos, saúde e ambiente. Cadernos de Saúde Pública, 21, 1836-1844. https://doi.org/10.1590/S0102-311X2005000600033

[6] Slovic, P. (2000) The Perception of Risk. Earthscan, New York.

[7] Santos, N., Roxo, M.J. and Neves, B. (2018) O Papel da percepcao no estudo de riscos naturais.

https://www.researchgate.net/publication/251754388_O_papel_da_percepcao_no_e studo_dos_riscos_naturais

[8] Dos Santos, G.F. (1996) Vale do Garcia (Blumenau-SC): análise climato-geomorfológica e a repercussão dos episódios pluviais no espaço urbano. Tese submetida a Pós Graduação em Geografia da Universidade de São Paulo. Universidade de São Paulo (USP), São Paulo.

[9] Aumond, et al. (2009) Desastre de 2008 no Vale do Itajaí: água, gente e política. 
Agência de Água do Vale do Itajaí, Blumenau. http://www.comiteitajai.org.br

[10] Rogerio, P.R.G. and Aumond, J.J.O. (2011) Manual do Deslizamento: um guia para a compreensão de deslizamentos. EDIFURB, Blumenau.

[11] Blumenau (2017) SIGAD 2016-Sistema de Informações Gerenciais de Apoio a Decisão. Prefeitura Municipal de Blumenau, Blumenau. http://www.furb.br/ips/sigad

[12] Macedo, D.R. and Magalhoes Junior, A.P. (2012) Percepção social no programa de restauração de cursos d'água urbanos em Belo Horizonte. Sociedade e Natureza, Uberlândia, 23, 51-63. http://www.scielo.br/pdf/sn/v23n1/05.pdf

[13] Bolfarine, H. and Bussabi, W.O. (2005) Sampling Elements. Publisher Blucher, Sao Paulo. 